\title{
Research on the Talent Training of the Management Direction of Horse Racing Industry in Colleges and Universities
}

\author{
Peng Ding \\ School of Physical Education, Wuhan Business University \\ Wuhan, 430056, China \\ 949808799@qq.com
}

\begin{abstract}
Through the analysis of current education situation in management direction of horse racing industry in Wuhan Business School, this paper aims to find out the existing problems in cultivating talents, put forward reasonable suggestions on the management education of horse racing industry to provide ideas and strategies that can be used for reference to the existing problems by those colleges and universities which want to cultivate talents of horse racing industry, thereby realizing the sustainable development of management education of the horse racing industry.
\end{abstract}

Keywords-Colleges and universities; Management of horse racing industry; The cultivation of talents; Training target

I. THE GOAL OF TALENT TRAINING OF THE SOCIAL SPORTS GUIDANCE MAJOR(MANAGEMENT DIRECTION OF HORSE RACING INDUSTRY)

The goal of training talents is the direction of education in Colleges and universities. It is the decisive factor to guide the teaching, and it is also the basic standard to evaluate the quality of the training of the talents in the school. The accuracy of orientation of the goal is directly related to the quality of talent training. Combined with the successful mode of foreign higher vocational education and the current situation of vocational education in China, the Ministry of Education issued the opinions of the Ministry of Education on improving the teaching quality of Higher Vocational Education in an all-round way (Jiao Gao [2006], 16). No. 16 explicitly put forward: "the higher vocational education should fully implement the party's education policy, take service as the purpose, take the employment as the orientation, take the combined development path of production and learning and to develop high-quality and technological talents for the need in the first line towards production, construction, service, and management for the construction of socialist modernization ".

Under the background of vigorous development of national social sports, relying on the advantages of horse racing (horsemanship) in Wuhan, we will serve the development of regional economy, and train high-quality skilled talents with the focus of training new talents in the emerging, fashion and high-end social sports. Wuhan Business School of social sports major ( management direction of horse racing industry) according to the orientation of running a school, so it comes to the following the overall goals of management direction of horse racing industry : it is mainly open for Hubei province and other regions in China, serving to the horse racing industry, support the party's basic line, adapting to the needs of the horse racing industry, having good occupation morals and the spirit of dedication, mastering the basic knowledge and skills of management in horse racing industry, cultivating the high-quality and all-round talents who are able to engage in organization and management of horse racing events and horse house, jockey and leisure riding guidance work

Specifically speaking, they are the graduates of management direction of horse racing industry who have the ability to engage in the ride; have practical operational ability on horse breeding, care, prevention and treatment of common diseases; have the ability on daily management of horse house and track maintenance skills; have the ability on organization and management of horse racing events, race judging and the ability of the planning of business event competition; have the ability on planning and guiding equestrian leisure activities.

The training goals of the management direction of horse racing industry in Wuhan Business School is in line with the demand for talents in the development of horse racing industry.

\section{CURRICULUM SYSTEM FOR TRAINING TALENTS OF MANAGEMENT DIRECTION OF HORSE RACING INDUSTRY}

According to the direction of the professional talent training goals and combined with the new development and requirements of related fields of the horse racing industry, management direction of the horse racing industry in Wuhan Business School strengthens the intensity of curriculum reform that focus on training the high-quality talents with outstanding skills and good social adaptation ability.

First of all, the basic task of curriculum construction as well as the major work are identified clearly: one is to strengthen the construction of professional core courses, to renew teaching contents and guide the interactive teaching and learning based on the standard of course teaching, in order to realize the goals of coordinated development of knowledge, ability and quality; two is to put emphasis on creating the 
project of teaching quality, in order to promote the development of curriculum construction.

Secondly, the curriculum design focused on the following points: the limitation on the total course number, giving priority on professional core curriculum and ensure the practice teaching proportion; vigorously promoting quality education and strengthen the technical application ability; advocating the educational philosophy that teaching students according to their aptitude and focus on the personality development of students; paying attention to implement the principle of curriculum design that combines basic theoretical knowledge and learning with enhancing the professional ability.

\section{THE EXISTING PROBLEMS IN TALENT TRAINING OF THE MANAGEMENT DIRECTION OF HORSE RACING INDUSTRY IN WUHAN BUSINESS SCHOOL}

\section{A. The mode of talent training need to be further discussed}

At present, the management direction of social horse racing industry in Wuhan Business School highlights the cooperation between schools and enterprises, strengthens the post work tasks, and persists in combining practice teaching assessment with professional qualification certification, so as to train scarce talents for industries and enterprises. The mode of training talents is in line with the actual needs of the economic and social development in Hubei and Wuhan and the conditions of school running. But at the same time, we should also realize that the horse racing industry in addition to the attribute of sports, but also relates to some fields such as animal husbandry, tourism, management and other fields, so it is a multidisciplinary integrated field that can be expected that the current training mode needs to be further studied while the industry gradually mature.

\section{B. The quality of teaching faculty needs to be further improved}

Since the management education of China's horse racing industry has just started. At present, almost all the full-time teachers are not professional origin of horse racing management major. They are mostly from other sports related majors. Therefore, they not only lack theoretical knowledge, but also lack practical experience. Teachers training pays more attention to horse technology training, but lacks theoretical and practical training in management, marketing and service. As a new discipline, teaching materials, syllabus and teaching methods are also scarce.

\section{The management of implementation process and the evaluation system is not perfect enough in practical teaching}

Although the Wuhan Business School has set up a series of management regulations on practical teaching, the efficiency of implementation is not high enough. The related supervision mechanism is not perfect, and the management of the teaching process is not in place. The part of practice teaching of management direction is going on at Orient Lucky City and there is no specific management system to the practical teaching of management direction of horse racing industry, and the evaluation of practical teaching has not set standards and evaluation is too monotonous.

\section{The lack of professional materials}

The horse racing industry in Europe and the United States and Japan, Australia and other countries is a very important industry. The industry branch also has a long history, but in the domestic, horse racing industry has just started and has yet to see a comprehensive and systematic exposition about the teaching of management direction, horse racing industry club operation and management. It is also necessary to strengthen the construction of teaching materials for the social sports guidance major (the management direction of horse racing industry).

\section{CONCLUSION AND SUGGESTIONS}

\section{A. To further adjust and enrich the talent training mode}

As for the curriculum design and subject construction, it not only needs to study the professional and general university requirements on sports, but also requires a combination of the specific characteristics of the profession, and doing a lot ongoing research of the direction of professional development in accordance with the needs of the teaching reality, to promote the curriculum design to be more scientific and reasonable, especially for the relevant areas of action and learning design according to the typical tasks of the management direction of horse racing industry, to determine a talent training mode that has the characteristics of management direction of horse racing industry.

\section{B. To reform and innovate the curriculum system of management direction of horse racing industry}

In the process of curriculum design, we should change the old idea and firmly establish the "people-oriented" and "student-centered" concept. In the process of cultivating talents, its focus is not only on the development of students' short-term, but also to the long-term development, and to further reform and innovate curriculum system and to construct a curriculum system based on professional ability.

According to the requirements of related posts of horse racing industry and the knowledge transformation rule to design the knowledge, ability and quality structure and training programs of students to optimize their knowledge structure, strengthen students' comprehensive occupation quality, and improve their adaptability to practical work on horse racing industry. 


\section{To strengthen the joint running with the horse racing club and related enterprises}

The combination of production and learning and the cooperation between school and enterprise are the basic ways to cultivate high-quality skilled talents to adapt to the social needs of the horse racing industry. We should actively explore and expand the mode of cooperation with the horse racing club and related enterprises as well as the way of cultivating talents in combination with "production and learning".

We should know the development situation and development trend of horse racing industry in the world and strengthen communication with related experts, scholars and people. We also should pay attention to the advice of experts during the research work. The establishment of expert counsel system can be tried, and the advisers' advice should be taken into consideration in accordance with the prescribed procedures when the major decisions are made in the work. The curriculum system is constructed with the experts of the horse racing club to make the trained talents more practical and pertinent.

\section{To improve the evaluation system of practice-oriented teaching}

In view of the current evaluation system and specific teaching practice, there are certain drawbacks, so that further improvement and perfection of the mechanism of evaluation system for practice teaching is needed, so as to better realize students' innovative learning and independent learning through the evaluation means, and in order to promote the students' creativity and expertise can be played effectively.

In addition, there is strong need to strengthen the dynamic and all-round management of personnel management. There should be timely feedback and timely treatment for talent quality related information, and to strengthen enterprise and social communication for timely understanding of the society, the demand of enterprise, and take it into the important content of teaching evaluation.

\section{E. To strengthen the construction of teaching faculty}

The management direction of horse racing industry has a higher demand for teachers, and the teachers in this field are short of teachers at present. In view of this situation, there are several adjustment suggestions for the current situation: (1) exchange abroad regularly (or to Hongkong) to learn advanced experience of management education in horse racing industry abroad or Hongkong area. (2) actively strengthen school and enterprise joint training school teachers, according to the relevant requirements, school could select the professional teachers and teaching management personnel to the Jockey Club for attachment to exercise every year, and according to the requirements of China Equestrian Association, school could select teachers at all levels to participate in the race organization and referee work, and hire outstanding jockey club managers to school as part-time teachers. (3) young teachers should be encouraged to study for doctor's degree and improve their educational level.

\section{$F$. To strengthen the social service function of the training base of vocational education in the management direction of horse racing industry}

The horse race simulation training room and standard racecourse is mainly open for the training and learning of students of management direction of horse racing industry, but it can also be reasonable arranged for school teachers and students as well as the public to provide services such as riding and fitness, and also riding training. It can increase students' internship opportunities and enhance students' organization and service ability so the income can also be used for the horse race simulation training room for maintenance and standard racecourse. At the same time, it can also expand the influence of this major in society and attract more partners, and broaden employment channels for students.

\section{ACKNOWLEDGMENT}

Foundation project: The research project of provincial higher education school of Hubei Province

Project name: Research on Equestrian Sports in Colleges and Universities and the Orientation of Talent Training Goals of Management Direction and Curriculum Design---take Wuhan Business School as an example

Project number: 2016425

\section{REFERENCES}

[1] Xia Yunjian. Research on Talent Training Mechanism of Industry and Learning Cooperation of Management Major in Horse Racing Industry [J]. Journal of Wuhan Commercial Service College, 2010.24(1):22-24.

[2] Cha Jide. New thinking on the orientation of talent training Goals in Higher Vocational Education [J]. China Vocational and Technical Education, 2011(18):12-19.

[3] Some Opinions on Improving the Teaching Quality of Higher Vocational Education of the Ministry of Education, Jiao Gao [2006], 16.

[4] Qiu Tongbao,Gao Jianhong. The orientation of the knowledge, ability, and quality structure of higher vocational talents in large scale [J]. Vocational Education Forum, 2006(10).

[5] Li Yaonan. Research on the Deeply Cooperation Between Colleges and Enterprises of Management Direction of Horse Racing Industry [J]. Journal of Wuhan Commercial Service College, 2011.25(4):71-73. 